\title{
Coprothermobacter platensis sp. nov., a new anaerobic proteolytic thermophilic bacterium isolated from an anaerobic mesophilic sludge
}

\author{
C. Etchebehere, ${ }^{1}$ M. E. Pavan, ${ }^{3}$ J. Zorzópulos, ${ }^{2,3}$ M. Soubes ${ }^{1}$ and L. Muxí ${ }^{1}$
}

Author for correspondence: C. Etchebehere. Fax : 5982924 1906. e-mail : cetchebe $a$ bilbo.edu.uy

\footnotetext{
1 Departamento de Microbiología, Facultad de Química y Facultad de Ciencias, Universidad de la República, C. C.1157, Montevideo, Uruguay

2 Departamento de Microbiología, Universidad de Buenos Aires, Buenos Aires, Argentina

3 Laboratorio de Biotecnología, Fundación P. Cassará, Buenos Aires, Argentina
}

\begin{abstract}
A new anaerobic, proteolytic, moderately thermophilic bacterium, strain $3 \mathbf{R}^{\mathbf{T}}$, was isolated from a methanogenic mesophilic reactor treating protein-rich wastewater. The cells were Gram-negative, non-spore-forming, non-motile rods. The DNA base composition was $43 \mathrm{~mol} \% \mathrm{G}+\mathrm{C}$. The optimum pH and temperature for growth were 7.0 and $55{ }^{\circ} \mathrm{C}$ respectively. The bacterium fermented gelatin, casein, bovine albumin, peptone and yeast extract. Glucose, fructose, sucrose, maltose and starch were poorly fermented. The major fermentation products from glucose were acetate, $\mathrm{CO}_{2}$ and $\mathrm{H}_{2}$ and, from gelatin, propionate was also detected. Growth on glucose was stimulated by thiosulfate, which was reduced to sulfide. Sulfate and nitrate were not reduced. 16S rRNA gene analysis revealed that the isolated bacterial strain was phylogenetically related to Coprothermobacter proteolyticus $(96.3 \%$ sequence similarity), the only known species within the genus. DNA-DNA hybridization analysis demonstrated a very low level of homology, indicating that the isolated strain and C. proteolyticus were not related at species level. Therefore, it is proposed to classify the described strain in the genus Coprothermobacter as a new species, Coprothermobacter platensis. The type strain of C. platensis is strain $3 R^{\top}$ (= DSM 11748').
\end{abstract}

Keywords: Coprothermobacter platensis sp. nov., proteolytic bacteria, thermophiles, anaerobe, thiosulfate reduction

\section{INTRODUCTION}

Anaerobic digestion is increasingly used for carbon decontamination of agroindustrial wastewaters (Speece, 1996). Proteins are frequently a major component of such wastes, and their degradation, initiated by extracellular proteases, is often incomplete (McInerney, 1988). The vast majority of full-scale digestors are mesophilic, however thermophilic treatment is also being explored as it may have advantages, especially for effluents produced at high temperature (Lettinga, 1995). To start thermophilic reactors, mesophilic anaerobic sludge may be adapted by gradually increasing the incubation temperature (Van Lier et al., 1993).

Although proteolytic activity is a common characteristic among mesophilic bacteria, very few anaerobic, thermophilic proteolytic bacteria have been characterized. In the past 10 years four novel genera have been described, namely Thermobrachium (Engle et al., 1996), Anaerobranca (Engle et al., 1995), Caloramator
(Tarlera et al., 1997) and Coprothermobacter (Ollivier et al., 1985; Rainey \& Stackebrandt, 1993; Kersters et al., 1994). Among them, the genus Coprothermobacter (formerly classified as Thermobacteroides) represents a very deep-branching phylum within the domain $B a c$ teria, with only one species, Coprothermobacter proteolyticus, reported so far (Rainey \& Stackebrandt, 1993). The other genera, Anaerobranca, Thermobrachium and Caloramator, are related to the clostridia, belonging to the large low $\mathrm{G}+\mathrm{C}$ content branch of the Grampositive division (Rainey et al., 1993; Collins et al., 1994).

In this paper, we describe a novel species within the genus Coprothermobacter, Coprothermobacter platensis, isolated from a methanogenic mesophilic reactor treating a protein-rich wastewater. Furthermore, we present evidence of the ability of both species of Coprothermobacter to use thiosulfate as an electron acceptor. Many mesophilic facultative anaerobes and strict anaerobes share this physiological trait. Among the thermophiles and hyperthermophiles of the do- 
main Bacteria, it has been reported for the genera Thermoanaerobacter and Thermoanaerobacterium (Lee et al., 1993) and more recently for Thermotogales (Fardeau et al., 1997; Ravot et al., 1995, 1996).

\section{METHODS}

Strains. Coprothermobacter proteolyticus $\mathrm{BT}^{\mathrm{T}} \quad(\mathrm{T}=$ type strain) (DSM 5265 ) was obtained from DSMZ (Deutsche Sammlung von Mikroorganismen und Zellkulturen, Braunschweig, Germany).

Enrichment and isolation. A sample $(5 \mathrm{ml})$ taken from the sludge of a mesophilic anaerobic digester treating wastewater from baker's yeast production in Montevideo, Uruguay, was anaerobically transferred to $50 \mathrm{ml}$ of BCYT medium - a basal medium containing yeast extract (Difco; $1 \mathrm{~g} \mathrm{l}^{-1}$ ) and triptone (Difco; $1 \mathrm{~g} \mathrm{l}^{-1}$ ) (Touzel \& Albagnac, 1983) - supplemented with glucose $\left(5 \mathrm{~g} \mathrm{l}^{-1}\right)$ and gelatin (Sigma; $5 \mathrm{~g}^{-1}$ ). Gelatin and glucose were used to enrich the medium because many thermophilic glycolytic anaerobes exhibit protease activity (Wiegel, 1992). This medium was prepared as previously described (Muxí et al., 1992), sparged with $\mathrm{N}_{2} / \mathrm{CO}_{2}(80: 20, \mathrm{v} / \mathrm{v})$, autoclaved for $15 \mathrm{~min}$ at $121^{\circ} \mathrm{C}$ and reduced with filter-sterilized sulfide-cysteine solution (Touzel \& Albagnac, 1983). Enrichments were incubated at $55^{\circ} \mathrm{C}$ and examined for growth with a phase-contrast microscope (Axioplan; Zeiss). Positive cultures were transferred periodically to fresh medium by using $10 \%(\mathrm{v} / \mathrm{v})$ inocula. Isolation was performed in plates with the same medium solidified with agar $(1.8 \%, \mathrm{w} / \mathrm{v})$ and incubated at $55^{\circ} \mathrm{C}$ in an anaerobic chamber (Coy Laboratory Products) with a gas atmosphere containing $\mathrm{N}_{2} / \mathrm{H}_{2} / \mathrm{CO}_{2}(80: 10: 10$, by vol.). After $10 \mathrm{~d}$, a colony was picked and reisolated twice in the same medium. Purity was checked microscopically and by growth in the same medium incubated anaerobically and aerobically at $55^{\circ} \mathrm{C}$. A purified strain $\left(3 \mathrm{R}^{\mathrm{T}}\right)$ was grown under $\mathrm{N}_{2}$ atmosphere, in pre-reduced $\mathrm{PY}$ broth medium - a basal medium containing peptone (Difco; $10 \mathrm{~g} \mathrm{l}^{-1}$ ) and yeast extract (Difco; $10 \mathrm{~g} \mathrm{l}^{-1}$ ) (Smibert \& Krieg, 1994)-and stored at room temperature.

Substrate utilization and end product formation. Substrate utilization was determined in pre-reduced BC medium (BCYT medium without tryptone and with yeast extract $\left.0 \cdot 2 \mathrm{~g} \mathrm{l}^{-1}\right)$. Stock solutions of soluble substrates $\left(100 \mathrm{~g} \mathrm{l}^{-1}\right)$ were anaerobically prepared, filter sterilized and anaerobically dispensed into tubes containing pre-reduced $\mathrm{BC}$ medium $(10 \mathrm{ml})$ with a $\mathrm{N}_{2}$ atmosphere. Insoluble substrates were weighed and transferred to culture tubes. Then, BC medium was dispensed $(10 \mathrm{ml})$ into the tubes under an $\mathrm{N}_{2}$ atmosphere and autoclaved. The complex substrates, bovine albumin (Sigma), xylan (Sigma), cellulose (Sigma), gelatin (Sigma), peptone (Difco), yeast extract (Difco), casein (Merck) and starch (Fluka), were added to a final concentration of $5 \mathrm{~g} \mathrm{l}^{-1}$. For the other substrates, a final concentration of $2 \mathrm{~g} \mathrm{l}^{-1}$ was used. Growth was measured spectrophotometrically (Genesys 5; Spectronic, Milton Roy) at $660 \mathrm{~nm}$. In cultures containing insoluble substrates, growth was monitored by microscopic examination and by analysis of end products (volatile fatty acids). The effect of sulfate, nitrate and thiosulfate on growth was tested using BCYT medium, supplemented with equimolar concentrations of glucose $(20 \mathrm{mM})$ and electron acceptor $(20 \mathrm{mM})$.

Analytical procedures. Fermentation products, volatile fatty acids and alcohols were measured by HPLC using a refractive index detector (Waters Millipore) with an OA 1000
(Alltech Associates) column. The mobile phase was $\mathrm{H}_{2} \mathrm{SO}_{4}$

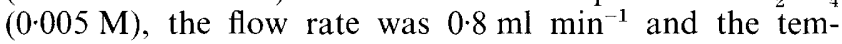
perature was $35^{\circ} \mathrm{C}$. Hydrogen was measured by gas chromatography using a $14 \mathrm{~A}$ gas chromatograph with a thermal conductivity detector (Shimadzu), equipped with a Carbosieve S II column and argon as the gas carrier. The flow rate was $30 \mathrm{ml} \mathrm{min}-1$ and the initial temperature was $35^{\circ} \mathrm{C}$, with an increase of $32{ }^{\circ} \mathrm{C} \mathrm{min}-1$ up to $225^{\circ} \mathrm{C}$. Anions (nitrate, nitrite, sulfate) were meseaured by HPLC using a UV detector (Shimadzu) and an ICPAK ANION (Waters Millipore) column, with a flow rate of $1.2 \mathrm{ml} \mathrm{min}^{-1}$ and a temperature of $42{ }^{\circ} \mathrm{C}$. The mobile phase was phosphate buffer $(0.01 \mathrm{M}, \mathrm{pH} 6.8)$. Sulfide was detected by the methylene blue method (Rand et al., 1975). Gelatin was measured as described by Bradford (1976).

Growth conditions. Optimum $\mathrm{pH}$, temperature and $\mathrm{NaCl}$ concentration ranges for growth were determined in PY medium, using a $5 \%(\mathrm{v} / \mathrm{v})$ inoculum. The optimum $\mathrm{pH}$ was determined by incubating cultures at $55^{\circ} \mathrm{C}$ at initial $\mathrm{pH}$ values from $4 \cdot 3$ to $9 \cdot 1$ adjusted by adding $\mathrm{NaOH}$ or $\mathrm{HCl}$. The optimum concentration of $\mathrm{NaCl}$ was determined at $\mathrm{pH} 7$ and $55^{\circ} \mathrm{C}$.

Susceptibility tests. Antibiotic resistance was determined in liquid $\mathrm{PY}$ medium at $\mathrm{pH} 7$ and $55^{\circ} \mathrm{C}$. Antibiotics were filter sterilized and the following concentrations were tested: vancomycin $\left(2.5\right.$ and $\left.5.0 \mathrm{mg} \mathrm{l}^{-1}\right)$, neomycin $\left(0 \cdot 15 \mathrm{~g} \mathrm{l}^{-1}\right)$, polymyxin $\mathrm{B}\left(20\right.$ and $\left.40 \mathrm{mg} \mathrm{l}^{-1}\right)$, penicillin $\mathrm{G}\left(20 \mathrm{U} \mathrm{ml}^{-1}\right)$, kanamycin $\left(300\right.$ and $\left.600 \mathrm{ng} \mathrm{ml}^{-1}\right)$, sodium azide $(0.5$ and $1 \cdot 0 \mathrm{~g} \mathrm{l}^{-1}$ ).

Protease assays. Protease activity was assayed using the azocasein method under anaerobic conditions $\left(\mathrm{N}_{2}\right.$ atmosphere) as described by Brock et al. (1982). The specific activity (in units) was expressed as $\mu \mathrm{g}$ azocasein hydrolysed $\mathrm{h}^{-1}$ (mg bacterial protein $)^{-1}$. Protein was determined as described by Bradford (1976).

Electron microscopy. For electron microscopic studies, the culture was centrifuged for $5 \mathrm{~min}$ at 3000 r.p.m. The supernatant was discarded and the pellet fixed in glutaraldehyde $(2 \%)$ in sodium cacodylate buffer $(0 \cdot 1 \mathrm{M})$ at $\mathrm{pH} 7 \cdot 4$ for $30 \mathrm{~min}$. The process was repeated, the pellet was then washed in phosphate buffer ( $\mathrm{pH} \mathrm{7.4)}$ and post-fixed with osmium tetroxide $(1 \%)$. Specimens were dehydrated in an ascending gradient of ethanol $(50,70,80,90$ and $95 \%)$ and then impregnated in propylene oxide. Finally, they were embedded in Poly/Bed 812 resin (Polysciences 18976-2590). Ultrathin sections were cut with an ultratome Super Nova (Reichter-Jung) and mounted in a copper grid, stained with uranyl acetate and lead citrate and examined in a JEM-1200 Ex II transmission electron microscope at $80 \mathrm{kV}$.

DNA base composition. DNA was isolated (Sambrook et al., 1989) and the G + C content was determined by HPLC at the DSMZ (Mesbah et al., 1989).

DNA-DNA hybridization. The genetic relatedness of strains was determined by DNA-DNA hybridization on nylon membranes (Johnson, 1991). Serial dilutions of DNA in denaturation solution $(0.5 \mathrm{M} \mathrm{NaOH}, 1.5 \mathrm{M} \mathrm{NaCl})$ were applied to a Pall Biodyne nylon membrane. The membrane was neutralized with $1.5 \mathrm{M} \mathrm{NaCl}, 0.5 \mathrm{M}$ Tris $/ \mathrm{HCl} \mathrm{pH} 8$ and baked for $2 \mathrm{~h}$ at $80^{\circ} \mathrm{C}$. Prehybridization $(2 \mathrm{~h})$ and hybridization $(18 \mathrm{~h})$ were performed at $65^{\circ} \mathrm{C}$ in hybridization buffer containing $0.15 \mathrm{M} \mathrm{NaCl}, 1 \%$ (w/v) SDS, $0.3 \%$ skim milk, using as a probe chromosomal DNA from strain $3 \mathrm{R}^{\mathrm{T}}$, digested with the $A l u$ I endonuclease and ${ }^{32}$ P-labelled using the Random Primers DNA Labelling System (Gibco BRL). 

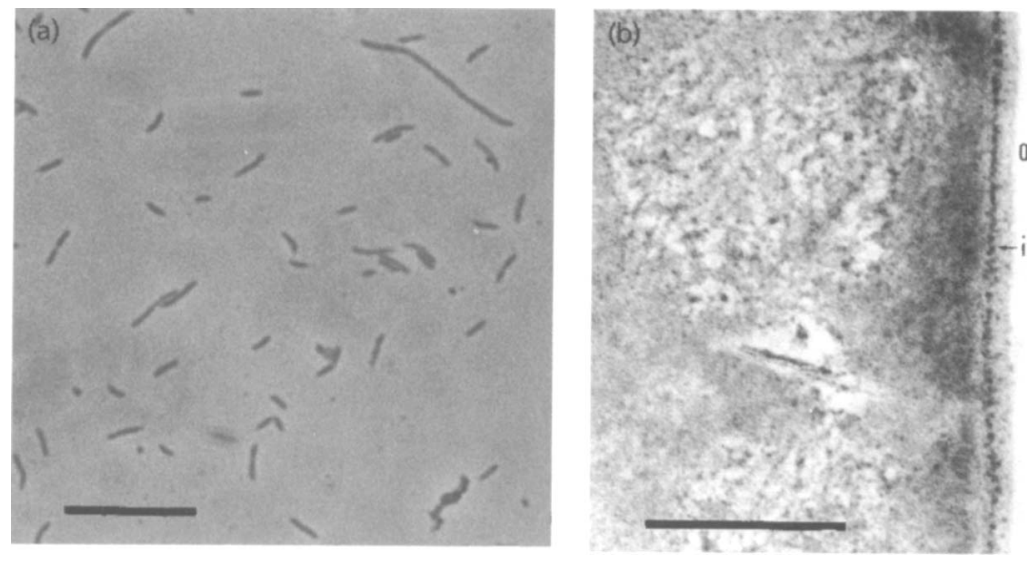

Fig. 1. (a) Phase-contrast micrograph of strain $3 \mathrm{R}^{\top}$ grown on $\mathrm{PY}$ medium, showing straight rods ocurring as single cells, in pairs or in chains. Bar, $10 \mu \mathrm{m}$. (b) Ultrathin section electron micrograph of strain $3 R^{\top}$ showing the cell wall structure. An intensely stained inner layer (i) and a less densely stained outer layer (o) were observed. Bar, $0.2 \mu \mathrm{m}$.

The results were scored by autoradiography. Similarity values were calculated as described by Johnson (1991).

Sequence analysis of $16 \mathrm{~S}$ rDNA and phylogenetic analysis. DNA from strain 3R ${ }^{\mathrm{T}}$ was purified (Sambrook et al., 1989) and the ribosomal $16 \mathrm{~S}$ genes were amplified by PCR (Johnson, 1994), using the following universal primers: 1492R (5'-GGTTACCTTGTTACGACTT-3'), corresponding to positions $1510-1492$ in reverse Escherichia coli numbering, and 27F (5'-AGAGTTTGATCMTGGCTCAG-3'), corresponding to positions 8-27 in forward $E$. coli numbering. The following temperature cycles were performed: $94{ }^{\circ} \mathrm{C}$ for $5 \mathrm{~min}, 30$ cycles of $94^{\circ} \mathrm{C}$ for $60 \mathrm{~s}, 60^{\circ} \mathrm{C}$ for $60 \mathrm{~s}$ and $72{ }^{\circ} \mathrm{C}$ for $60 \mathrm{~s}$, followed by a final $7 \mathrm{~min}$ incubation at $72{ }^{\circ} \mathrm{C}$. The PCR products were purified using WIZARD PCR Preps columns (Promega). The PCR product was manually sequenced using the fmol DNA Sequencing kit (Invitrogen). The 16S rDNA sequence was aligned, using the CLUSTAL $\mathrm{v}$ program, with similar sequences belonging 10 various members of the domain Bacteria retrieved from the EMBL database and the Ribosomal Database Project (Maidak et al., 1994). Only unambiguously aligned positions were used for phylogenetic analysis (1235 positions, from 227 to 1416 by $E$. coli numbering, were selected). An unrooted tree was constructed using the DNADIST (Jukes \& Cantor option) and the NEIGHBOR-JOINING programs contained in the PHYLIP Phylogeny Inference Package, version 3.5 (Felsenstein, 1993). A bootstrap analysis (1000 replicates) was also performed using a program included in the same package.

\section{RESULTS}

\section{Enrichment and isolation of strain $\mathbf{3} \mathbf{R}^{\top}$}

The bacterial strain used in this study was isolated from a mesophilic anaerobic wastewater digester at a baker's yeast factory located in Montevideo, Uruguay. Bacterial growth was evident after incubation in glucose-gelatin medium at $55^{\circ} \mathrm{C}$ within $5-7 \mathrm{~d}$ after inoculation. Microscopic examination of this primary enrichment culture revealed micro-organisms with diverse morphologies, but after eight subcultures small, rod-shaped cells were dominant. Purification was performed on agar plates incubated at $55^{\circ} \mathrm{C}$ under anaerobic conditions. After $10 \mathrm{~d}$ incubation, colonies were about $1 \mathrm{~mm}$ in diameter, circular with smooth margins, transparent to whitish. A single colony was picked and purified. This purified strain, designated $3 \mathrm{R}^{\mathrm{T}}(\mathrm{T}=$ type strain $)$, was characterized.

\section{Morphology and cell structure}

Cells of strain $3 \mathrm{R}^{\mathrm{T}}$ grown in $\mathrm{PY}$ medium were nonmotile, straight rods, occurring singly or in pairs (Fig. 1a). They were generally $1.5-2 \mu \mathrm{m}$ long and $0.5 \mu \mathrm{m}$ wide. Long chains were also observed in old cultures. Spores were never observed, and the cultures did not survive a heat treatment of $2 \mathrm{~h}$ at $90^{\circ} \mathrm{C}$. Lysis was observed in late stationary phase. Young cultures of strain $3 \mathrm{R}^{\mathrm{T}}$ stained Gram-negative but had a negative $\mathrm{KOH}$ test (Gregersen, 1978). Electron micrography of thin sections revealed a cell wall with an intensely stained inner layer and a less densely stained outer layer (Fig. 1b).

\section{Physiological characteristics}

(i) Growth requirements. Strain $3 \mathrm{R}^{\mathrm{T}}$ required strictly anaerobic conditions for growth. The addition of $0.02 \%$ yeast extract was necessary for growth in medium with glucose as sole carbon source. The temperature range for growth at $\mathrm{pH} 7$ was $35-65^{\circ} \mathrm{C}$, with an optimum at $55^{\circ} \mathrm{C}$. The $\mathrm{pH}$ range for growth at $55^{\circ} \mathrm{C}$ was $4 \cdot 3-8 \cdot 3$, with an optimum at $7 \cdot 0$. During growth at $\mathrm{pH}$ values close to neutrality, the $\mathrm{pH}$ decreased by not more than 0.4 units. The doubling time under optimal conditions in PY medium was $16 \cdot 1 \mathrm{~h}$. Growth was inhibited in PY medium supplemented with $\mathrm{NaCl}$ to a concentration of $0.4 \mathrm{M}$ or higher.

(ii) Substrate utilization and fermentation products. Cells of strain $3 \mathrm{R}^{\mathrm{T}}$ were proteolytic. Growth was observed using gelatin, casein, bovine albumin and other proteinaceous substrates, such as yeast extract and peptones, as energy sources. An extracellular protease activity was demonstrated for cells grown on gelatin. Protease activity increased during growth, showing a maximum of $116 \pm 20 \mathrm{U}$ at the end of the exponential growth phase. 
C. Etchebehere and others

Table 1. Effect of thiosulfate on growth of Coprothermobacter proteolyticus $B T^{\top}$ and strain $3 \mathrm{R}^{\top}$

Optical density, sulfide and glucose were measured after $7 \mathrm{~d}$ incubation at $55^{\circ} \mathrm{C}$ for C.proteolyticus $\mathrm{BT}^{\mathrm{T}}$ and after $9 \mathrm{~d}$ for strain $3 R^{\prime \prime}$.

\begin{tabular}{|c|c|c|c|c|c|c|}
\hline \multirow[t]{2}{*}{ Growth conditions } & \multicolumn{3}{|c|}{ C. proteolyticus $\mathrm{B}^{\mathrm{T}}$} & \multicolumn{3}{|c|}{ Strain $3 R^{T}$} \\
\hline & $O D_{660}$ & $\begin{array}{c}\mathrm{H}_{2} \mathrm{~S} \\
(\mathrm{mM})\end{array}$ & $\begin{array}{c}\text { Glucose } \\
\text { consumed }(\%)\end{array}$ & $\mathrm{OD}_{660}$ & $\begin{array}{c}\mathrm{H}_{2} \mathrm{~S} \\
(\mathrm{mM})\end{array}$ & $\begin{array}{c}\text { Glucose } \\
\text { consumed }(\%)\end{array}$ \\
\hline Basal medium* & $0 \cdot 145$ & $3 \cdot 2$ & - & $0 \cdot 109$ & $3 \cdot 5$ & - \\
\hline Basal medium + glucose $\dagger$ & $0 \cdot 387$ & $3 \cdot 2$ & 58 & $0 \cdot 210$ & $3 \cdot 8$ & 19 \\
\hline Basal medium + glucose + thiosulfate $\dagger$ & $0 \cdot 756$ & $20 \cdot 6$ & 100 & $1 \cdot 132$ & $23 \cdot 5$ & 100 \\
\hline
\end{tabular}

* Basal medium $\mathrm{BC}$ supplemented with yeast extract $\left(1 \mathrm{~g} \mathrm{l}^{-1}\right)$ and tryptone $\left(1 \mathrm{~g} \mathrm{l}^{-1}\right)$.

$\dagger$ Glucose $(20 \mathrm{mM})$ was used as substrate and thiosulfate $(20 \mathrm{mM})$ as electron acceptor.

Table 2. Main characteristics of strain $3 \mathrm{R}^{\top}$, Coprothermobacter proteolyticus and Thermobacteroides leptospartum

\begin{tabular}{|c|c|c|c|}
\hline Character & Strain $3 R^{T}$ & C. proteolyticus* & T. leptospartum $\dagger$ \\
\hline Morphology & Short rods, pleomorph & Short rods, pleomorph & Long, thin rods \\
\hline Optimum pH & $7 \cdot 0$ & $7 \cdot 5$ & $7 \cdot 5$ \\
\hline Optimum temperature $\left({ }^{\circ} \mathrm{C}\right)$ & 55 & 63 & 60 \\
\hline Maximum temperature $\left({ }^{\circ} \mathrm{C}\right)$ & 65 & 70 & 71 \\
\hline $\mathrm{G}+\mathrm{C}$ content $(\mathrm{mol} \%)$ & 43 & 45 & 43 \\
\hline Fermentation end products from glucose & Acetate, $\mathrm{H}_{2}, \mathrm{CO}_{2}$ & Acetate, $\mathrm{H}_{2}, \mathrm{CO}_{2}$ & Ethanol, acetate \\
\hline Thiosulfate reduction to sulfide & + & + & NR \\
\hline Proteolytic & + & + & + \\
\hline \multicolumn{4}{|l|}{ Utilization of: } \\
\hline Glucose & + & + & + \\
\hline Sucrose & + & + & - \\
\hline Fructose & + & + & - \\
\hline Maltose & + & + & + \\
\hline Xylose & - & + & + \\
\hline Starch & + & + & NR \\
\hline \multicolumn{4}{|l|}{ Growth in the presence of antibiotics } \\
\hline Vancomycin $\left(2 \cdot 5 \mathrm{mg} \mathrm{l}^{-1}\right)$ & - & + & + \\
\hline Neomycin $\left(0 \cdot 15 \mathrm{~g} \mathrm{l}^{-1}\right)$ & - & - & - \\
\hline Polymixin $\mathrm{B}\left(20 \mathrm{mg} \mathrm{l}^{-1}\right)$ & - & + & - \\
\hline Sodium azide $\left(0.5 \mathrm{~g}^{-1}\right)$ & + & + & + \\
\hline Kanamycin $\left(600 \mathrm{ng} \mathrm{l}^{-1}\right)$ & + & + & NR \\
\hline Penicillin $\mathrm{G}\left(20 \mathrm{U} \mathrm{ml}^{-1}\right)$ & + & - & + \\
\hline Isolated from & $\begin{array}{l}\text { Mesophilic anaerobic } \\
\text { reactor }\end{array}$ & $\begin{array}{l}\text { Thermophilic anaerobic } \\
\text { reactor }\end{array}$ & Cattle manure \\
\hline
\end{tabular}

NR, Not reported.

* Data from this study, Ollivier et al. (1985) and Kersters et al. (1994).

$\dagger$ Data from Toda et al. (1987).

Cells of strain $3 \mathrm{R}^{\mathrm{T}}$ were also able to grow on glucose, fructose, sucrose, maltose and starch. However, xylose, lactose, sorbitol, glycerol, inositol, xylans and cellulose were not fermented. After growth in BC medium supplemented with glucose $\left(2 \mathrm{~g} \mathrm{l}^{-1}\right), 10 \%$ of the glucose was consumed and the major fermentation products were acetate $(2.1 \mathrm{mM})$, hydrogen $(2.3 \mathrm{mM})$ and $\mathrm{CO}_{2}$ (not determined). After growth in $\mathrm{BC}$ medium supplemented with gelatin $\left(5 \mathrm{~g} \mathrm{l}^{-1}\right), 80 \%$ of the gelatin was consumed and the major fermentation products were acetate $(5.6 \mathrm{mM})$, hydrogen $(1.1 \mathrm{mM})$ and propionate $(1.9 \mathrm{mM})$. Butyrate $(4.6 \mathrm{mM})$, isobutyrate (traces) and isovalerate (traces) were detected in similar amounts as in control cultures in BC medium. Growth on glucose was not affected by the addition of nitrate or sulfate. However, thiosulfate had a pronounced effect on growth and glucose utilization by strain $3 \mathrm{R}^{\mathrm{T}}$ and $C$. proteolyticus $\left(\mathrm{BT}^{\mathrm{T}}\right)$ (Table 1$)$. 


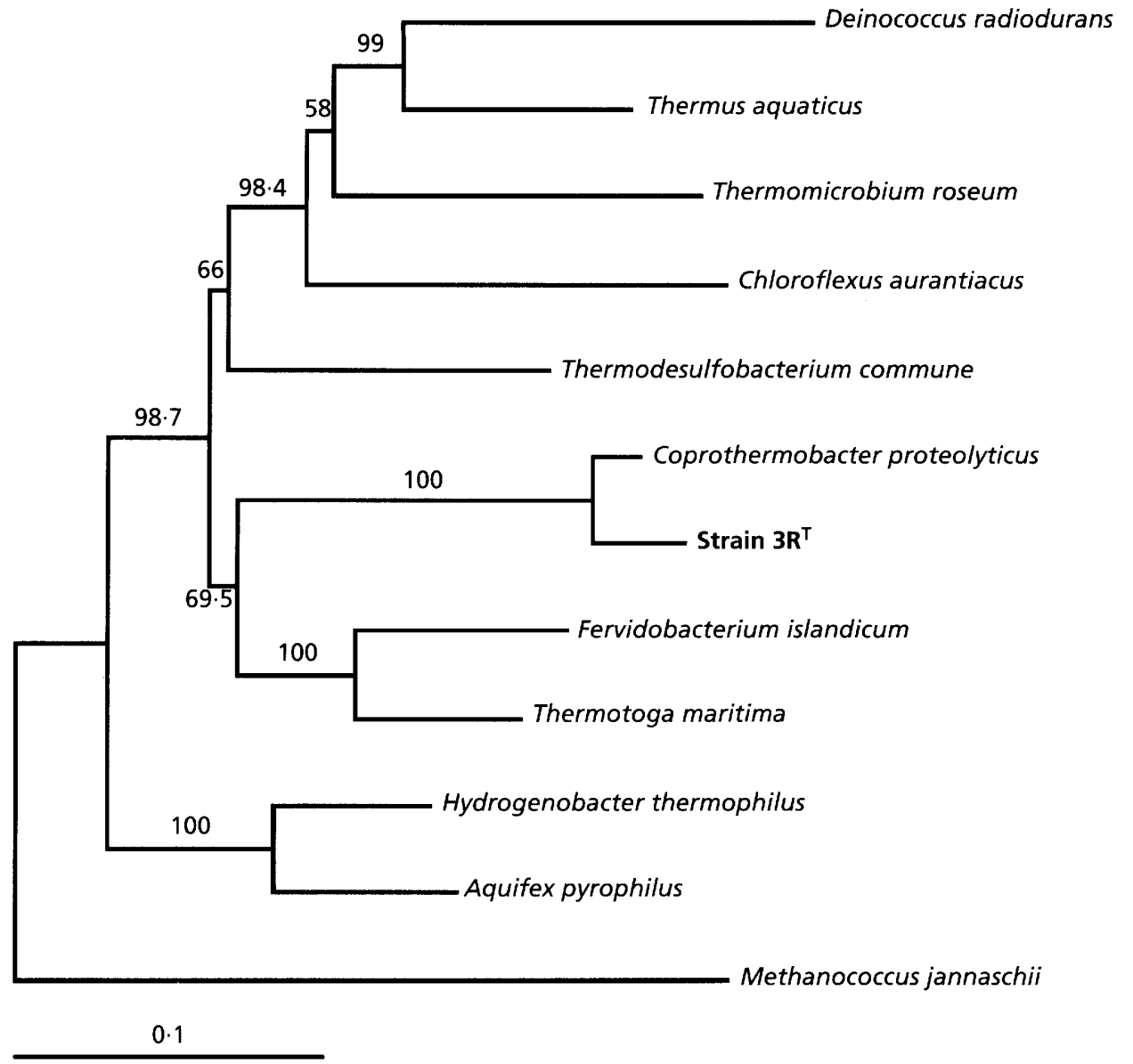

Fig. 2. Phylogenetic tree derived from $16 \mathrm{~S}$ rDNA sequence data analysis, showing the position of strain $3 R^{\top}$. The bar corresponds to evolutionary distance of 0.1 . The numbers shown next to the nodes indicate percentage bootstrap values from 1000 data sets. The EMBL accession numbers for the sequences used in the phylogenetic analysis were as follows: Aquifex pyrophilus strain Ko15a', M83548; Choloroflexus aurantiacus strain J-10-fl' $\mathrm{T}^{\top}$ M34116; Coprothermobacter proteolyticus strain ATCC 35245', X69335; Deinococcus radiodurans strain ATCC 35073, M21413; Fervidobacterium islandicum strain $\mathrm{H}_{21}{ }^{\top}$, M59176; Thermotoga maritima strain $\mathrm{MSB}^{\top}{ }^{\top}, \mathrm{M}^{21774}$; Thermomicrobium roseum strain ATCC $27502^{\top}, \mathrm{M} 34115$, Thermodesulfobacterium commune strain YSRA-1 ${ }^{\top}$, L10662; Thermus aquaticus strain X-1, X58340; Hydrogenobacter thermophilus strain TK- ${ }^{\top}, \mathrm{Z} 30214$; Methanococcus jannaschii strain JAL-1 ${ }^{\top}, \mathrm{M} 59126$.

(iii) Antibiotic susceptibility. Growth of strain $3 \mathrm{R}^{\mathrm{T}}$ was inhibited by vancomycin $\left(2 \cdot 5 \mathrm{mg} \mathrm{l}^{-1}\right)$, neomycin $(0 \cdot 15 \mathrm{~g}$ $\left.\mathrm{I}^{-1}\right)$ and polymyxin $\mathrm{B}\left(20 \mathrm{mg}^{-1}\right)$. Inhibition was not detected in the presence of penicillin $\mathrm{G}\left(20 \mathrm{U} \mathrm{ml}^{-1}\right)$, kanamycin $\left(600 \mathrm{ng} \mathrm{ml}^{-1}\right)$ or sodium azide $\left(0.5 \mathrm{~g} \mathrm{l}^{-1}\right)$ (Table 2).

\section{DNA base composition}

The $\mathrm{G}+\mathrm{C}$ content of strain $3 \mathrm{R}^{\mathrm{T}}$ was $43 \mathrm{~mol} \%$.

\section{Phylogenetic analysis}

A total of 1446 nucleotides of the $16 \mathrm{~S}$ rDNA gene were sequenced from positions 30 to 1481 according to $E$. coli numbering. Comparison with rDNA sequences available in databases revealed that strain $3 \mathrm{R}^{\mathrm{T}}$ is related to Coprothermobacter proteolyticus and peripherically related to species of the genera Thermotoga and Fervidobacterium. The percentage sequences similarities, corrected for multiple changes by the method of Jukes \& Cantor, obtained from the phylogenetic distances matrix, were $96.3 \%$ for Coprothermobacter proteolyticus, $76.1 \%$ for Thermotoga maritima and $75 \cdot 2 \%$ for Fervidobacterium islandicum, followed by Thermodesulfobacterium commune $(73.4 \%)$ and $\mathrm{Hy}$ drogenobacter thermophilus $(73 \cdot 3 \%)$. According to the phylogenetic analysis (Fig. 2) strain $3 \mathrm{R}^{\mathrm{T}}$ and Coprothermobacter proteolyticus are in the same clade. However DNA-DNA hybridization analysis demonstrated less than $12 \%$ similarity between the chromosomal DNAs of these bacteria.

\section{DISCUSSION}

The new isolate, strain $3 \mathrm{R}^{\mathrm{T}}$, is an anaerobic, moderately thermophilic, proteolytic bacterium. To our knowledge, six anaerobic, thermophilic, proteolytic micro-organisms of the domain Bacteria have been described in the past 10 years: Coprothermobacter proteolyticus (Rainey \& Stackebrandt, 1993), formerly 
Thermobacteroides proteolyticus (Ollivier et al., 1985), Thermobacteroides leptospartum (Toda et al., 1988), Clostridium P2 (Örlygsson, 1994), Anaerobranca horikoshii (Engle et al., 1995), Thermobrachium celere (Engle et al., 1996) and Caloramator proteoclasticus (Tarlera et al., 1997). The last four belong to the large low $\mathrm{G}+\mathrm{C}$ content branch of the Gram-positive division of the domain Bacteria (Rainey et al., 1993; Collins et al., 1994). The phylogenetic position of Thermobacteroides leptospartum remains unknown, while Coprothermobacter proteolyticus belongs to one of the deepest divisions of the domain Bacteria (Rainey \& Stackebrandt, 1993).

The phylogenetic analysis indicated that strain $3 \mathrm{R}^{\mathrm{T}}$ clusters with Coprothermobacter proteolyticus. This result was supported by the high bootstrap value ( $100 \%$ of 1000 replicates). The closest relatives are Thermotoga maritima and Fervidobacterium islandicum, both members of the order Thermotogales. However, the phylogenetic relationship between the genus Coprothermobacter and the Thermotogales is still uncertain, as suggested by the low bootstrap value $(69.5 \%)$ and the short evolutionary distance of the common branch.

The level of 16S rDNA sequence similarity between strain $3 \mathrm{R}^{\mathrm{T}}$ and C. proteolyticus, the only species in the genus so far, was $96.3 \%$. It has been proposed that strains sharing less than $97 \%$ similarity usually do not belong to the same species (Stackebrandt \& Goebel, 1994). Furthermore, the level of chromosomal DNADNA homology between the strains, as measured by hybridization techniques, was less than $12 \%$, far below the threshold value of $70 \%$ recommended for species delineation (Wayne et al., 1987). According to these results, strain $3 \mathrm{R}^{\mathrm{T}}$ can be considered as a new species within the genus Coprothermobacter.

Table 2 shows some characteristics of the two species of the genus Coprothermobacter and of Thermobacteroides leptospartum, which originally belonged to the same genus as Coprothermobacter proteolyticus. There are no significant differences in optimum $\mathrm{pH}$ and $\mathrm{G}+\mathrm{C}$ content of the chromosomal DNAs. Strain $3 \mathrm{R}^{\mathrm{T}}$ and Coprothermobacter proteolyticus show similar morphology and fermentation products, differing in both aspects from Thermobacteroides leptospartum. Strain $3 \mathrm{R}^{\mathrm{T}}$ differs from C. proteolyticus and Thermobacteroides leptospartum in optimum temperature for growth, antibiotic susceptibility and sugar utilization.

We also tested the ability of strain $3 \mathrm{R}^{\mathrm{T}}$ and Coprothermobacter proteolyticus strain $\mathrm{BT}^{\mathrm{T}}$ to reduce thiosulfate with glucose as substrate. Thiosulfate was reduced to sulfide by both strains, and its addition clearly stimulated glucose utilization and growth, as was reported for, among others, Thermotoga, Fervidobacterium (Fardeau et al., 1997; Ravot et al., 1995) and Thermosipho species (Ravot et al., 1996). This property has not been previously reported for members of the genus Coprothermobacter. Further studies are necessary to elucidate the mechanism of thiosulfate reduction by bacteria of the Coprothermobacter genus as well as its ecological relevance.

According to the physiological and phylogenetic characteristics of strain $3 \mathrm{R}^{\mathrm{T}}$, we propose the creation of a new species within the genus Coprothermobacter to be named Coprothermobacter platensis sp. nov.

\section{Description of Coprothermobacter platensis sp. nov.}

Coprothermobacter platensis (pla.ten'sis. L. masc. adj. pertaining to Rio de la Plata, a river between Uruguay and Argentina, the region from where the strain was isolated).

Cells are straight rods, $0.5 \times 1 \cdot 5-2.0 \mu \mathrm{m}$, that occur singly or in pairs in young cultures. Long chains are present in old cultures. Lysis is observed in the stationary phase. Colonies in PY agar plates are circular, $1 \mathrm{~mm}$ in diameter, with an entire border, transparent to whitish. Stains Gram-negative but the cell wall under the electron microscope is atypical with a dense inner layer and a less dense outer layer. Nonmotile, non-spore-forming. Obligately anaerobic. Proteolytic. Ferments gelatin, casein, bovine albumin, peptone and yeast extract. Glucose, fructose, sucrose, maltose and starch are poorly fermented. Fermentation products from glucose are acetate, $\mathrm{H}_{2}$ and $\mathrm{CO}_{2}$. The major fermentation products from gelatin are acetate, propionate, $\mathrm{H}_{2}$ and $\mathrm{CO}_{2}$. Growth on glucose is stimulated by thiosulfate, which is reduced to sulfide. Sulfate and nitrate are not reduced. Moderately thermophilic, optimum temperature $55^{\circ} \mathrm{C}$ (range $35-$ $65^{\circ} \mathrm{C}$ ). Optimum pH 7.0 (range 4.3-8.3). Yeast extract is required. Growth is inhibited by vancomycin $(2.5 \mathrm{mg}$ $\left.\mathrm{1}^{-1}\right)$, neomycin $\left(0 \cdot 15 \mathrm{~g}^{-1}\right)$ and polymyxin $\mathrm{B}(20 \mathrm{mg}$ $\left.\mathrm{l}^{-1}\right)$. Resistant to penicillin $\mathrm{G}\left(20 \mathrm{U} \mathrm{ml}^{-1}\right)$, kanamycin $\left(600 \mathrm{ng} \mathrm{ml}^{-1}\right)$ and sodium azide $\left(0 \cdot 5 \mathrm{~g} \mathrm{l}^{-1}\right)$. $\mathrm{NaCl}, 0 \cdot 4 \mathrm{M}$ or higher, is inhibitory. The $\mathrm{G}+\mathrm{C}$ content of DNA is $43 \mathrm{~mol} \%$ as determined by HPLC. Phylogenetically closely related to Coprothermobacter proteolyticus according to the $16 \mathrm{~S}$ rDNA sequence analysis. Both are included in one of the earlier branches of the domain Bacteria. Isolated from a mesophilic upflow anaerobic sludge blanket reactor of a baker's yeast factory. The type strain is strain $3 \mathrm{R}^{\mathrm{T}}$ (= DSM $11748^{\mathrm{T}}$ ).

\section{ACKNOWLEDGEMENTS}

We thank Dr Petruccelli from Universidad de la Plata, Argentina, for the electron microscopy studies and Dr J. Castiglioni from LAFIDESU, Facultad de Química, Uruguay, for hydrogen determinations. We also gratefully acknowledge Dr F. Rainey for critically reading the manuscript. This work was supported by a grant from PEDECIBA-Quimica (a programme for the development of basic sciences in Uruguay).

\section{REFERENCES}

Bradford, M. M. (1976). A rapid and sensitive method for the quantitation of microgram quantities of protein utilizing the principle of protein-dye binding. Anal Biochem 72, 248-254.

Brock, F. M., Forsberg, C. W. \& Buchanan-Smith, J. G. (1982). 
Proteolytic activity of rumen microorganisms and effects of proteinase inhibitors. Appl Environ Microbiol 44, 561-569.

Collins, M. D., Lawson, P. A., Willens, A., Cordoba, J. J., Fernandez-Garayzabal, J., Garcia, P., Hippe, H. \& Farrow, J. A. E. (1994). The phylogeny of the genus Clostridium: proposal of five new genera and eleven new species combinations. Int $J$ Syst Bacteriol 44, 812-826.

Engle, M., Li, Y., Woese, C. \& Wiegel, J. (1995). Isolation and characterization of a novel alkalitolerant thermophile, Anaerobranca horikoshii gen. nov., sp. nov. Int J Syst Bacteriol $\mathbf{4 5}$, 454-461

Engle, M., Li, Y., Rainey, F., DeBlois, S., Mai, V., Reichert, A., Mayer, F., Messner, P. \& Wiegel, J. (1996). Thermobrachium celere gen. nov., sp. nov., a rapidly growing thermophilic, alkalitolerant, and proteolytic obligate anaerobe. Int $J$ Syst Bacteriol 46, 1025-1033.

Fardeau, M.-L., Ollivier, B., Patel, B. K. C., Magot, M., Thomas, P., Rimbault, A., Rocchiccioli, F. \& Garcia, J.-L. (1997). Thermotoga hypogea sp. nov., a xylanolytic, thermophilic bacterium from an oil-producing well. Int J Syst Bacteriol 47, 1013-1019.

Felsenstein, J. (1993). PHYLIP (Phylogeny Inference Package) version $3.5 p$. Distributed by the author. Department of Genetics, University of Washington, Seattle, USA.

Gregersen, L. (1978). Rapid method for distinction of gram negative from gram positive bacteria. $J$ Appl Biochem 5, 123-126

Johnson, J. L. (1991). DNA reassociation experiments. In Nucleic Acid Techniques in Bacterial Systematics, pp. 21-44. Edited by E. Stackebrandt \& M. Goodfellow. New York: Wiley.

Johnson, J. L. (1994). Similarity analysis of rRNAs. In Methods for General and Molecular Bacteriology, pp. 683-700. Edited by P. Gerhardt, R. G. E. Murray, W. A. Wood \& N. R. Krieg. Washington, DC: American Society for Microbiology.

Kersters, I., Maestrojuan, G. M., Torck, U., Vancanneyt, M., Kersters, K. \& Verstraete, W. (1994). Isolation of Coprothermobacter proteolyticus from an anaerobic digest and futher characterization of the species. Syst Appl Microbiol 17, 289-295.

Lee, Y. E., Jain, M. K., Lee, C., Lowe, S. E. \& Zeikus, J. G. (1993). Taxonomic distinction of saccharolytic thermophilic anaerobes: description of Thermoanaerobacter xylanolyticum gen. nov., sp. nov., and Thermoanaerobacterium saccharolyticum gen. nov., sp. nov., reclassification of Thermoanaerobium brokii, Clostridium thermosulfurogenes, and Clostridium thermohydrosulfuricum E100-69 as Thermoanaerobacter brokii comb. nov., Thermoanaerobacterium thermosulfurigenes comb. nov., and Thermoanaerobacter thermohydrosulfuricus comb. nov., respectively: and transfer of Clostridium thermohydrosulfuricum 39E to Thermoanaerobacter ethanolycus. Int J Syst Bacteriol 43, $41-51$.

Lettinga, G. (1995). Anaerobic digestion and wastewater treatment systems. Antonie Leeuwenhoek 67, 3-28.

McInerney, M. J. (1988). Anaerobic hydrolysis and fermentation of fats and proteins. In Biology of Anaerobic Microorganisms, pp. 373-415. Edited by A. J. B. Zehnder. New York: Wiley.

Maidak, B. L., Larse, M. J., McCaughey, R., Overbeek, G. J., Fogel, K., Blandy, J. \& Woese, C. (1994). The Ribosomal Database Project. Nucleic Acids Res 22, 3485-3487.

Mesbah, M., Premanchandran, U. \& Whitman, W. B. (1989). Precise meisurement of the $\mathrm{G}+\mathrm{C}$ content of deoxyribonucleic acid by high performance liquid chromatography. Int $J$ Syst Bacteriol 39, 159-167.

Muxí, L., Zunino, L., Tarlera, S. \& Soubes, M. (1992). Charac- terization of a methanogenic sludge to be used as inoculum for a high-rate reactor. World J Microbiol Biotechnol 8, 632-634.

Ollivier, B. M., Mah, R. A., Ferguson, T. J., Boone, D. R., García, J. L. \& Robinson, R. (1985). Emendation of the genus Thermobacteroides: Thermobacteroides proteolyticus sp. nov., a proteolytic acetogen from a methanogenic enrichment. Int $J$ Syst Bacteriol 35, 425-428.

Örlygsson, J. (1994). The role of interspecies hydrogen transfer on the thermophilic protein and amino acid metabolism. $\mathrm{PhD}$ thesis, Swedish University of Agricultural Sciences.

Rainey, F. A. \& Stackebrandt, E. (1993). Transfer of the type species of the genus Thermobacteroides to the genus Thermoanaerobacter as Thermoanaerobacter acetoetylicus (Ben-Bassat and Ziekus 1981) comb. nov., description of Coprothermobacter gen. nov., and reclassification of Thermobacteroides proteolyticus as Coprothermobacter proteolyticus (Ollivier et al., 1985) comb. nov. Int J Syst Bacteriol 43, 857-859.

Rainey, F. A., Ward, N. L., Morgan, H. W., Toalster, R. \& Stackebrandt, E. (1993). Phylogenetic analysis of anaerobic thermophilic bacteria: aid for their reclassification. Int J Syst Bacteriol 175, 4772-4778.

Rand, M. C., Greenberg, A. E. \& Taras, M. J. (1975). Sulfide, methylene blue method. In Standard Methods for the Examination of Water and Wastewater, 14th edn, pp. 503-505. Washington, DC: American Public Health Association, American Water Works Association and Water Pollution Control Federation.

Ravot, G., Ollivier, B., Magot, M., Patel, B. K. C., Crolet, J. L., Fardeau, M.-L. \& Garcia, J. L. (1995). Thiosulfate reduction, an important physiological feature shared by members of the order Thermotogales. Appl Environ Microbiol 61, 2053-2055.

Ravot, G., Ollivier, B., Patel, B. K. C., Magot, M. \& Garcia, J. L. (1996). Emended description of Thermosipho africanus as a carbohydrate fermenting species using thiosulfate as an electron acceptor. Int $J$ Syst Bacteriol 46, 321-323.

Sambrook, J., Fritsch, E. F. \& Maniatis, T. (1989). Molecular Cloning: a Laboratory Manual, 2nd edn. Cold Spring Harbor, NY: Cold Spring Harbor Laboratory.

Smibert, R. M. \& Krieg, N. R. (1994). Phenotypic characterization. In Methods for General and Molecular Bacteriology, pp. 611-651. Edited by P. Gerhardt, R. G. E. Murray, W. A. Wood \& N. R. Krieg. Washington, DC: American Society for Microbiology.

Speece, R. E. (1996). Anaerobic Biotechnology for Industrial Wastewaters, pp. 3-6. Nashville, TN: Vanderbilt University Press.

Stackebrandt, E. \& Goebel, M. (1994). Taxonomic note: a place for DNA-DNA reassociation and 16rRNA sequence analysis in the present species definition in bacteriology. Int $J$ Syst Bacteriol 44, 846-849.

Tarlera, S., Muxí, L., Soubes, M. \& Stams, A. J. M. (1997). Caloramator proteoclasticus sp. nov., a new moderately thermophilic anaerobic proteolytic bacterium. Int $J$ Syst Bacteriol 47, 651-656.

Toda, Y., Saiki, T., Uozumi, T. \& Beppu, T. (1988). Isolation and characterization of a protease-producing, thermophilic anaerobic bacterium, Thermobacteroides leptospartum sp. nov. Agric Biol Chem 52, 1339-1344.

Touzel, J.P. \& Albagnac, G. (1983). Isolation and characterization of Methanococcus mazeii strain MC3. FEMS Microbiol Lett 16, 241-245.

Van Lier, J. B., Hulsbeek, J., Stams, A. J. M. \& Lettinga, G. (1993). 
C. Etchebehere and others

Temperature susceptibility of thermophilic methanogenic sludge: implications for reactor start-up and operation. Bioresource Technol 43, 227-235.

Wayne, L. G., Brenner, D. J., Colwell, R. R. \& 9 others (1987).

Report of the Ad Hoc Committee on Reconciliation of

Approaches to Bacterial Systematics. Int J Syst Bacteriol 37 , 463-464

Wiegel, J. (1992). The obligately anaerobic thermophilic bacteria. In Thermophilic Bacteria, pp. 105-184. Edited by J. K. Kristjansson. Boca Raton, FL: CRC Press. 